\title{
Quality Constraints in the Market Chains for Export of Small Ruminants from Afar Pastoral and Agro-Pastoral Areas
}

\author{
Gezahegn Alemayehu*, Birhanu Hailu, Nuru Seid \\ College of Veterinary Medicine, Samara University, Samara, Ethiopia
}

Email address:

gezahegnayalew@yahoo.com (G. Alemayehu)

To cite this article:

Gezahegn Alemayehu, Birhanu Hailu, Nuru Seid. Quality Constraints in the Market Chains for Export of Small Ruminants from Afar Pastoral and Agro-Pastoral Areas. Animal and Veterinary Sciences. Vol. 3, No. 2, 2015, pp. 51-57. doi: 10.11648/j.avs.20150302.14

\begin{abstract}
The study was conducted in four districts of Afar Pastoral and Agro-pastoral Area to determine quality constraints in the market chains for export of Afar's small ruminants. A total of 291 producers, 8 traders and 4 exporters were interviewed with separate semi-structured questionnaires. The result of study indicated that small ruminant made by far the greatest contribution to livestock-based livelihoods in all study districts. About $72.2 \%$ of pastoralist offers shoat for sale to meet their urgent needs at any time during the year. Majority (51.9\%) of the producers have no specific target to sale their shoat. Quality and other criteria required by importers were known only by $7.6 \%$ of the producers, while majority of them (92.4\%) did not know quality and other criteria required by importer. Even though sheep were most demanded by exporters, sheep accounts only $20 \%$ from total shoat presented for sale. Only $14.4 \%$ of the producers offer adult male for sale which were fit for export. Along the market chain pre-purchase inspection and selection for quality assurance and certification for live shoat were none existent. In all Afar's livestock markets there is no objective standard for selling and buying animals. The result of this study showed that small ruminants supplied to the markets by pastoralist do not meet the quality attributes required by export markets. Appropriate extension service that will respond to the peculiar needs of export markets, especially on the aspect of providing information and knowledge on the desired shoat characteristics and quality requirements of importing countries should be provided for the producers.
\end{abstract}

Keywords: Afar, Export, Market, Small Ruminants, Quality

\section{Introduction}

Ethiopia is a resourceful country bestowed with the largest livestock resource in the Africa continent with about 54 million cattle, 25.5 million sheep and 24.06 million goats. From the total small ruminant population $99.8 \%$ of the sheep and nearly all goat population of the country are local breeds [1].

The livestock subsector has an enormous contribution to Ethiopia's national economy and livelihoods of many Ethiopians, and still promising to rally round the economic development of the country [2,3]. Livestock and livestock products export are among the major earners of foreign exchange for the Ethiopian economy. Of the total number of live animals exported 19\% was sheep. In shoat marketing system, $95 \%$ of the exported animals were sheep [4].

Of the total small ruminant population of the country, pastoralists own about 26 percent of sheep (about 6.5 million heads of sheep) and nearly two-third of the goats' population (about 15.2 million heads of goats) [5]. Sheep and goat are valued for a variety of important contributions in lives of pastoral households. Thus, pastoralists raise them with several objectives to meet the socio-economic and cultural need $[6,7]$. Small ruminants play an important role in financial security, women's empowerment and insurance. Pastoral areas output underpins almost all of Ethiopia's live animal and meat exports [8]. A large percentage of the live shoat and meat exported from Ethiopia originates from Afar pastoral area $[4,9]$.

Despite the reported high livestock population of the country, the major meat and live animal exporters are complaining of shortage of supply and inferior quality of animals (especially shoats). As the country has the largest number of livestock in Africa, Ethiopia has much to gain from the growing global market for livestock products. The problem faced by Ethiopia is thus one of enhancing its 
competitiveness in the international markets for live shoat and shoat meat in order to increase and maintain its market share. Nearly all Ethiopian live sheep and goat are exported to Saudi Arabia. This indicates live animals export from the country lack diversified export destinations. Additionally, Ethiopian market share and absolute exports to the Saudi market have declined in recent years while the share of the competitors increasing. Ethiopia's current share in the global market is very limited. In 2004, the share of Ethiopia was only $0.23 \%$ of global figure [10].

For small ruminant production to contribute its full potential to national economic growth and to support livelihood of the pastoral community require improving the efficiency of internal marketing systems and livestock export procedures, and improving product quality. With regard to quality, serious attention needs to be given to grades, standards and SPS measures, in compliance with international agreements of world trade organization (WTO). Ensuring product quality and reducing trade barriers, particularly in the rapidly integrating market of Europe will ensuring the profit of the livestock sectors and product business. Moreover, the country also benefits from the influx of foreign currency through revenue gained by exporting animals and meat. This is achieved mainly by improving quality of small ruminants supplied for exporters. Information on quality of small ruminants for export from Ethiopia in general and from Afar's in particular is highly scanty. Hence, there is a need for assessment of quality constraints in Afar's small ruminant market chain for export. The aim of this study was therefore to assess quality constraints in the market chains for export of small ruminants from Afar Pastoral and Agro-pastoral areas.

\section{Material and Methods}

\subsection{Study Areas}

The study was conducted in two zones of Afar Regional State namely in zone 1 and 3. Afar is one of nine regional states situated in the North-Eastern part of Ethiopia. The altitude of the region ranges from 1500 m.a.s.l. in the western highlands to -120 meters below sea level in the Danakil/Dallol depression. The regional capital, Samara is located in zone 1 (Dubti Woreda) some $588 \mathrm{Kms}$ North-east of Addis Ababa on the main Addis-Djibouti road. Afar is characterized by an arid and semi-arid climate with low and erratic rainfall. Temperature varies from $20^{\circ} \mathrm{C}$ in higher elevations to $48^{\circ} \mathrm{C}$ in lower elevations. Rainfall is bi-modal throughout the region with a mean annual rainfall below 500 $\mathrm{mm}$ in the semi-arid western escarpments decreasing to 150 $\mathrm{mm}$ in the arid zones to the east (Figure 1). There are 16 livestock markets in Afar regional state in which only $75 \%$ (14) of them are functional. The most important livestock markets in the region used for live shoat marketing are Adiatu, Ayisaita, Awash 7, Elewha, Chifra, Mille, Gedamayetu, Endufo, and Logia.

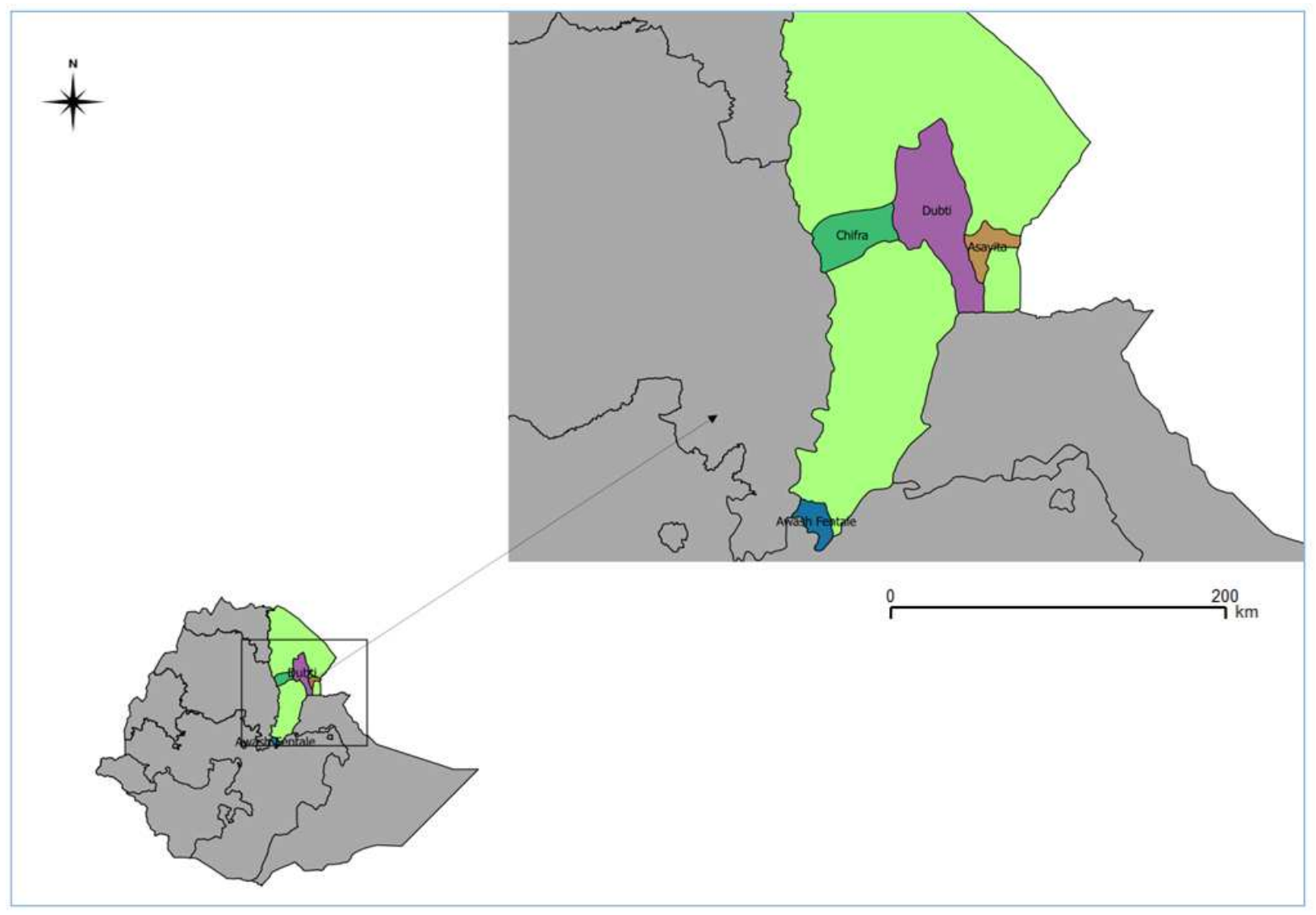

Figure 1. Study areas 


\subsection{Source of Information and Sampling Procedure}

At producers' level, four districts of Afar pastoral region namely Aysaita, Dubti, Chifra and Awash Fentale were selected purposely from the Afar regional states based on their relative importance of export quality shoat, relative importance of domestic vs. export market outlets, their geographical location and socioeconomic characteristics. A total of 291 producers, 8 traders and 4 exporters were interviewed with separate semi-structured questionnaires to collect information on quality constraints of traded shoat along export market chain.

\subsection{Data Collection and Analysis Technique}

A field surveys were conducted by means of three sets of semi-structured personal interview. The first set was designed for the producers to obtain information on shoat production, marketing, and their awareness on quality requirements for export. The other set was designed for traders to collect shoat supply pattern, shoat quality problems in the market, buying and selling system, their criteria to buy shoat and their awareness on quality requirements for export. The third set was design for exporters to collect shoat supply pattern, shoat quality problems in the market, buying and selling system, their criteria to buy, reason for shoat rejection and quality assurance system along the chain. Data from producers and traders were collected in each month in one of main market day found in each selected districts a period of one year during June 2013- October 2014. The data was subjected to statistical analysis using Statistical Package for Social Sciences (SPSS) software, version 20.0 (SPSS Inc., Chicago, Illinois, USA). Descriptive statistics such as frequency distribution and percentages were used.

\section{Results}

\subsection{Characteristics of Producers}

Table 1. Main source of livelihood for Afar's pastoral and Agro-pastoral community.

\begin{tabular}{lll}
\hline Livelihood dependence & Frequency & Percentage (\%) \\
\hline Only Livestock & 199 & 68.4 \\
Mainly livestock, minor crop & 42 & 14.4 \\
Mainly crop, minor livestock & 4 & 1.4 \\
Livestock and crop equally important & 12 & 4.1 \\
Livestock and other non agricultural & 34 & 11.7 \\
activities & 34 \\
\hline
\end{tabular}

The study showed that in Afar pastoral and agro-pastoral areas, livelihoods depend, at least in part, on livestock (Table 1). Small ruminant made by far the greatest contribution to livestock-based livelihoods in all study districts. The main benefit derived from small ruminants in the area was reported to be food, which include meat, milk and fat. The second most important benefit was income from sales of surplus animals. Other lesser benefits include various socio-cultural roles. Majority, $97.3 \%$ of the respondents practiced the free range (extensive) production system and only $2.7 \%$ of them practiced tethering (subsistence) system, while none of them practiced intensive livestock production system. Interview result indicated that $82.5 \%$ of males involved in shoat selling while only $17.5 \%$ of females involved in shoat selling.

\subsection{Quality Indicators at Producers'Level}

According interview result, $72.2 \%$ of pastoralist offers shoat for sale to meet their urgent needs at any time during the year. About $19.2 \%$ of the producers sale during drought due to feed shortage, while only $8.6 \%$ of the producers indicated that they supply shoat according to seasonal variation in demand and select the appropriate type of shoat according to function (Hajj, Ramadan or other holiday) ( Table 2).

Table 2. Major reasons of pastoralist and Agro pastoralist to sale their shoat.

\begin{tabular}{lll}
\hline Reason to sale & Frequency & Percentage (\%) \\
\hline Immediate cash need & 210 & 72.2 \\
During high demand & 25 & 8.6 \\
During Drought & 56 & 19.2 \\
Total & 291 & 100 \\
\hline
\end{tabular}

Furthermore, the survey result indicated that $12.4 \%$ producers targeted primarily restaurants to sell their shoat, while $23.3 \%$ and $4.5 \%$ targeted primarily household consumers and butchers respectively. While, majority $(51.9 \%)$ of the producers have no specific target to sale their shoat. Only $7.9 \%$ of producers targeted traders who supply shoat for export market (Table 3). The prices received by pastoralist were lower when they sold for traders compared to other costumers. Pastoralist indicated that they receive higher price when they sold during Hajj, Ramadan or other holiday (during high demand) compared to sale immediate cash need as well as drought. The lower price was paid for pastoralist when sold due to drought compared to sales for cash shortage and holiday.

Table 3. Target of the pastoralist and agro-pastoralist to sale their shoat.

\begin{tabular}{lll}
\hline Target customers & Frequency & Percentage (\%) \\
\hline Household consumers in urban area & 68 & 23.3 \\
Traders & 23 & 7.9 \\
Restaurants & 36 & 12.4 \\
Butchers & 13 & 4.5 \\
No specific target & 151 & 51.9 \\
Total & 291 & 100 \\
\hline
\end{tabular}

Quality and other criteria required by importers were known only by $7.6 \%$ of the producers, while majority of them $(92.4 \%)$ did not know quality and other criteria required by importer. Furthermore, only $18.2 \%$ of pastoralists informed about Afars' shoat are demanded by Middle East consumers. Majority of Afar's shoat were exported to Saudi Arabia markets. Quality requirements of shoat in Saudi market is presented in Table 4. The Saudi markets have a preference for Afar's sheep above $26 \mathrm{~kg}$ live weight. The animals should be no more than four years of age (three pairs of permanent incisor teeth). Large numbers of shoat are 
demanded mainly during Hajj and for religious purposes. During Hajj, live weight requirement of Saudi market of sheep is lower to $20-22 \mathrm{Kg}$. Compared to live goat; live sheep are more preferred by importers. In terms of breed, Afars' sheep are the most demanded by importers next to Somali black head.

Table 4. Quality requirements of live shoat for Saudi's markets from Ethiopia.

\begin{tabular}{ll}
\hline Products & Quality requirements \\
\hline Live sheep & Afar's and Somali black head breed \\
& 1. Above $28 \mathrm{Kg}$ live weight for Somali black head, above \\
& 26 KG live weight for Afar breed \\
& 2. Below 3 years age \\
& 3. Disease free \\
& 4.None castrated male \\
& 1. Desert local breed (Afar, Short eared Somali, Long \\
& eared Somali \\
2. Above 35kg for Afar, Above 40kg for Short eared \\
Live goat & Somali, Long eared Somali \\
& 3. Below 3 years age \\
& 4. Disease free \\
&
\end{tabular}

Against the above requirements and preferences in the Saudi market, from total shoat presented for sale, sheep accounts only $20 \%$. Majority of producers (40.9\%) indicated that they presented young male for sale and $28.2 \%$ of producers presented culled female shoat for sale. Only $14.4 \%$ of the producers offer adult male for sale which are fit for export. Characteristics of traded shoat in Afar region livestock markets are indicated in Table 5.

Table 5. Characteristics of traded shoat in Afar region livestock markets as reported by producers.

\begin{tabular}{lll}
\hline Characteristics & Frequency & Percentage (\%) \\
\hline Matured male & 9 & 3.1 \\
Adult male & 42 & 14.4 \\
Young male & 119 & 40.9 \\
Culled female & 82 & 28.2 \\
Breeding female & 10 & 3.4 \\
Male kid & 23 & 8 \\
Young female & 6 & 2 \\
Total & 291 & 100 \\
\hline
\end{tabular}

\subsection{Quality Indicators at Market Level}

Of four markets surveyed, all markets were fenced and all markets had loading and unloading facilities. None of these markets have water and feed trough and holding facilities. Except the market at Logia which meets 5 day per week, the rest of the markets meet 1 day per week.

Market survey indicated that at various points in market chain from primary market up to quarantine center, there was no veterinarian performing pre-purchase inspection and selection for quality assurance and certification for live shoat. The traded animals were not subjected to any tests before they were moved into quarantine. Per-purchase selections along the market chain have been conducted by traders or purchaser groups without necessary animal health knowledge.

In the markets, purchased decision was reached based on traders' physical evaluation of the animals while moving freely in the market by palpation of the shoat at points for fatness; tail, chest, back. Purchasers knew the age of the shoat using teeth eruption. The traders tried to select shoat with good general health and not emaciated, clean smooth glistening hair not rough coat, good appearance condition (active) and tried fulfill export quality criteria. The traders tried to avoid diseased animals (such as these having emaciation, diarrhoea, pneumonia and severe cases of mange).

Animals are not weighed in Afars' primary and secondary markets but the animals are weighed at export terminal markets. In all livestock markets there is no objective standard for selling and buying animals. Trader may buy a particular type of shoat, e.g. adult male, young male etc or a combination of types in a mob or batch as a unit or as single animals. Sales for exporters occurred in the same manner. Average price per animal from these combinations (or mix) differs greatly. The traders mix shoat different type and making a batch consisting of animals within a range of weight, e.g. underweight, medium or heavy weight to make a balanced batch to maximize net return form shoat. The price of the batch was fixed using shoat which was bought with high prices as bench mark.

\subsection{Quality Indicators at Quarantine Level}

Exporters exported live shoat to Saudi Arabia, Dubai, Oman and Beirut. Majority of them are exporting only Afra's sheep because of their adaptation to harsh environments and importers preference for sheep sourced from these areas. According to the discussion with exporters exporting live goat is very risky because of high mortality rate during 21 days confinement at quarantine station. Some exporters export immediately after they finished collection of goats without 21 days quarantine. Exporters collect sheep from either from the main source markets through their agents or from secondary markets found Bati and Methara. As part of SPS requirements and according to the rules and regulations of animal quarantine, shoats are exported after providing the shoat with necessary vaccines and medication. The exporter held sheep for 21 days in their own/rented quarantine center found in Methara, Awash 7 killo and Mile.

The facility receives only uncastrated male animals intended for export as live animals; they originate mainly from Afar and oromia region. All animals were bought as batch and arrived by truck. Previous health statuses of the admitted animals were not known. Those animals were not subjected to any tests before they were moved into facilities. There was no primary inspection at the point of entry before the animals are accepted for quarantine. Therefore, the sheep and goat were admitted into quarantine facilities with all their problems. After collections of the animals were completed, animals are examined individually and identified with ear tags before vaccination. Reasons for culling included suboptimum body condition and signs of clinical disease. 


\subsection{Quality Assurance System along Export Market Chain}

At market level there are no government veterinarians to perform inspection and selection for quality assurance and certification. Screaming of animals at the time of purchase was performed by purchase team on the basis of a number of criteria. The purchase team observe and inspect animals individually by visual assessment to avoid the following: inferior quality, over aged (full permanent teeth $>4$ years) or castrated, enlarged lymph nodes and abscesses, generalized mange, infected wounds, scratches, diarrhoea, or any disease which cannot respond to fast treatment, or will leave a scar on the body, phenotypical abnormalities on shoat body or its limbs.

At quarantine centers level, inspection and selection for quality assurance of export sheep is performed both by centers veterinarian and form Adama Quarantine Station. Before the animals were admitted to quarantine facilities, the veterinary authority from federal quarantine service through Adama quarantine station inspects the premises whether the facilities meet the required quarantine standards or not. To ensure completion of quarantine period, veterinary inspectors with technicians perform inspection and checking at entrance, vaccination and departure of quarantine premises.

During departure, the veterinary inspectors screen unfit animals using visual inspection. The leading causes of rejection at terminal export markets were underweight and sheep and goat pox. Other conditions leading to rejection during departure inspection include orf (contagious pustular dermatitis), mange, diarrhea, pneumonia and foot rot. Finally, after they reject unfit animals for export they issued certification for exported animals.

\section{Discussions}

Afar pastoral community is one of major pastoral groups in Ethiopia occupied northeast of the country. Afar pastoral areas are generally characterized by unpredictable and unstable climatic features where the potential for crop cultivation is limited. Therefore, livestock are centre of pastoral lives and livelihoods. Abdulahi [11] indicated that an estimated minimum of $93 \%$ of the population in pastoral areas is directly dependent on livestock for subsistence. The reported greatest contribution of small ruminant in livestockbased livelihoods in this study was also reported by Jost et al. [12] in North Eastern Province of Kenya in which small ruminant especially goats made the greatest contribution to livelihoods Kenyan pastoralist. The main benefits derived from small ruminants in the study areas was reported to be food, income, socio-cultural. Schwartz and Schwartz [13] indicated that the main functions of livestock production in pastoral households are to provide subsistence products (milk, blood and meat), to meet social obligations (bride price, stock alliances and stock patronages) and to insure against disaster (drought, epidemics, raids). Goats and sheep are valued as a source of meat, as well as a resource that can be sold for cash $[14,15]$. The reported extensive production practice in this study is one of the features of Ethiopian sheep and goat production system. Sheep and goats production in pastoral and agropastoral systems is of subsistence nature. Market-oriented or commercial production is almost nonexistent [16].

This study indicated that selling of shoat was done mainly by men. Ayele et al. [17] also reported higher percentages (92\%) male sellers in Ethiopia. Even though, women play a significant role in pastoral communities and are key agents in livelihood development, the great majority of pastoral societies continue to be dominated by men, and women's participation in decision-making processes is limited or totally absent. Decisions regarding herd mobility, planning, conflict resolution, and relations with neighboring groups are usually made by older men. With some exceptions, men own the animals and have sole rights to dispose of them through sale and slaughter [18].

The result of this study also showed that majority (72.2\%) of pastoralist offers shoat for sale to meet their urgent needs at any time during the year. This might be due to the fact that the small ruminant production system in the study areas is only for subsistence rather than market orientation. The extensive production systems that dominate small ruminant production in area not only inhibit producer access to market information, but limit the learning process on production changes required to meet the quality demands of the export market [19]. The study furthermore indicated that majority $(51.9 \%)$ of the producers have no specific target to sale their shoat. This indicated that the producers in study area did not offered quality shoat which responding export market demands but to satisfy their immediate cash need. In such a situation, the purchase price of an animal will reflect not only the bargaining skills of both buyers and sellers but also the buyer's preference for the characteristics of the animal and the seller's willingness to sell, sometimes leading to transaction failure [20].

In this study majority of producers $(92.4 \%)$ did not know quality and other criteria required by importer. Even though Afar sheep and goat breeds most preferred in the Middle East market $[4,19,21]$, only $18.2 \%$ of pastoralists informed about this. However, this information is well known to traders and exporters. Therefore, vertical linkage between traders and producers in terms of both forwards and backwards information would improve the pastoralist capacity to share information and learn strategies for responding to the market. Strengthened agribusiness linkages would improve the efficiency to respond to market demands [19].

The Saudi markets have a preference for uncastrated male Afar's sheep below 4 years and above $26 \mathrm{~kg}$ live weight. However, against these requirements and preferences in the Saudi market, sheep accounts only $20 \%$ total shoat presented for sale and only $14.4 \%$ of the producers offer adult male for sale which are fit for export. The preferences Afra's sheep may have been due to the breed's adaptation to harsh environments and importers preference for sheep sourced from these areas. Hailemariam et al. [4] indicated that in shoat marketing system, $95 \%$ of the exported live animals 
were sheep. This might be due to fact that exporting goat is much risky due to they fail to adapt 21 days of confinement at quarantine centers.

Along the market chain pre-purchase inspection and selection for quality assurance and certification for live shoat were none existant. Purchased decision was reached based on traders' physical evaluation of the animals while moving freely in the market by palpation of the shoat at points for fatness; tail, chest, back. Since there is no disease free zone in Ethiopia including Afar pastoral area [22, 23, 24, 25], some diseases, especially trade related (transboundary) diseases might pass undetected along the market chain. This could limit market supply of export quality animals by compromising most important quality criteria related to health and diseases.

In all Afar's livestock markets there is no objective standard for selling and buying animals. The traders buy shoat with visual estimation of live weight at both primary and secondary markets. This might increase the culling rate of shoat due to underweight at export terminal market since selling of shoat at export terminal conducted on per $\mathrm{kg}$ live weight basis of individual animal. Furthermore, buying animals as batch from traders (collectors) could increase the probability of inferior quality shoat inter the quarantine facilities.

Sheep and goat which were collected from producers were admitted to quarantine facilities which were found in Awash 7 , Methara and Mile for 21 days. The existing quarantine stations in Ethiopia are small in size and without adequate facilities and owned and run by private entrepreneurs but certification is only made by a "competent authority" [26]. This quarantine is not recognized by the Gulf Cooperation Council (GCC) countries, and animals must be re-quarantined at the port of export. For animals that go through the Djibouti quarantine the Ethiopian certification is neither required nor seen by the final recipient, as all animals are re-certified as Djibouti origin [21]. This practice is potentially leading to duplication of tests, doubling of quarantine waiting requirements, feed costs and the like. However, in order to bring the existing practice to an end and secure the country's proprietary rights, the government of Ethiopia on the way to finalized the constriction of large quarantine facilities at Mile area.

This study indicated biosecurity practice of the quarantine centers are none existent. This poor biosecurity measures in quarantine centers increase risk of the introduction and spread of disease agents within and between facilities. Introduction and spread of diseases in quarantine centers reduce the efficiency of production and thus it makes economic sense. Most stringent biosecurity requirements are concentrated on the people in the high-risk category, such as those who have direct contact with animals or manure on the farm, as well as other farms [27, 28]. Therefore, improving biosecurity practices is the most cost-effective in protection of animal diseases in quarantine facilities [29, 30].

There is also a need to emphasise issues of animal welfare in the in Ethiopian livestock trade, particularly in animal transport $[9,31,32]$. The trucks used for transport are not designed for the purpose and lack many biosafety measures.

Introducing traded animal into quarantine facilities without health certificate and any test along market chain resulting in high rates of rejection within quarantine facilities and between the export and import ports. Such high rejection rates cause severe financial hardship for the business owners by increasing the costs and reduce the competitiveness of the country. Importing countries such as Saudi Arabia are strict in screening unfit animals intermes of health and quality. Such action provides a good signal and an incentive to undertake inspection and screening in a serious manner.

\section{Conclusion}

The finding of this study indicated that livelihoods depend on livestock and small ruminant made by far the greatest contribution to livestock-based livelihoods in all study districts. The result further showed that small ruminant supplied to the market by pastoralist do not meet the quality attributes required by export markets. There was no government body which assures quality of traded animals along the export market chain. Appropriate extension service that will respond to the peculiar needs of export markets, especially on the aspect of providing information and knowledge on the desired shoat characteristics and quality requirements of importing countries should be provided for producers.

\section{Acknowledgment}

We would like to express our gratitude to all those who gave us the possibility to complete this research. We are very grateful to Adama quarantine station, live animal exporters and producers for his provision of valuable information for the research. Finally, and most importantly, we would like to express our deepest gratitude to Samara University research and community service vice president office for financial support for the research.

\section{References}

[1] CSA 2013. Agricultural Sample Survey, 2012/13 (2005 E.C.), Volume II: Report on Livestock and livestock characteristics (Private peasant holdings). Statistical Bulletin 570. Addis Ababa: Central Statistical Agency (CSA), Federal Democratic Republic of Ethiopia.

[2] Metaferia, F., Cherenet, T., Gelan, A., Abnet, F., Tesfay, A., Ali, J.A., Gulilat, W. 2011. A Review to Improve Estimation of Livestock Contribution to the National GDP. Ministry of Finance and Economic Development and Ministry of Agriculture, Addia Ababa, Ethiopia.

[3] Behnke, R. 2010. The Contribution of Livestock to the Economies of IGAD Member States: Study Findings, Application of the Methodology in Ethiopia and Recommendations for Further Work. IGAD LPI Working Paper 02-10. Great Wolford, UK: Odessa Centre, IGAD Livestock Policy Initiative. In. 
[4] Hailemariam, T., Legese, G., Alemu, D.,and Negassa, A. 2009. Market Structure and Function for Live Animal and Meat Exports in Some Selected Areas of Ethiopia. Research Report 79. EIAR, Addis Ababa, Ethiopia.

[5] SOS 2013. Pastoralism In Ethiopia: Its Total Economic Values and Development Challenges. SOS SAHEL ETHIOPIA, Addis Ababa, Ethiopia.

[6] Devendra, C. 2001. Small ruminants: imperative for productivity enhancement improved livelihood and rural growth. A review. Asian-Aust. J.Anim.sci. 14(10)1483-1496.

[7] Jahnke, H.E. 1982. Livestock Production Systems and Livestock Development in Tropical Africa. Kieler Wissenschaftsverlag Vauk.

[8] IGAD 2013. The Contribution of Livestock to the Ethiopian Economy. IGAD Center for Pastoral Areas \& Livestock Development (ICPALD). Policy Brief No: ICPALD 5/CLE/8/2013

[9] Legese, G., Hailemariam, T., Alemu, D.,and Negassa, A. 2008. Live animal and meat export value chains in prioritized areas of Ethiopia: Constraints and opportunities for enhancing meat exports. ILRI Discussion Paper 12. ILRI (International Livestock Research Institute), Nairobi, Kenya.

[10] FAO 2005. Addressing marketing and processing constraints that inhibit agri-food export. $A G S$ bulletin 160, FAO, Rome.

[11] Abdulahi, M. 2003. Pastoral Development Strategies/ Policies in Ethiopia: A Critical Analysis and Evaluation," Proceedings of the Third National Conference on Pastoral Development in Ethiopia, December 23-24, 2003, Addis Ababa. Pastoral Form Ethiopia: Addis Ababa

[12] Jost C.C, Nzietchueng S. , Kihu S. Bett, B. , Njogu G, Swai Emmanuel, and Mariner J. C. 2010. Epidemiological Assessment of the Rift Valley Fever Outbreak in Kenya and Tanzania in 2006 and 2007. Am. J. Trop. Med. Hyg., 83(Suppl 2) $65-72$.

[13] Schwartz, S. and Schwartz, H.J. 1985. Nomadic pastoralism in Kenya: still a viable production system? Quarterly Journal of International Agriculture, 24 (1): 5-21.

[14] Abdullahi, A.M. 1990. Pastoral Production Systems in Africa: A Study of Nomadic Household Economy and Livestock Marketing in Central Somalia. Farming Systems and Resource Economics in the Tropics, No.8. Kiel, Germany.

[15] Sieff, D.F. 1999. The effects of wealth on livestock dynamics among the Datoga pastoralists of Tanzania. Agricultural Systems, 59: 1-25.

[16] Gizaw S., Tegegne A., Gebremedhin B. and Hoekstra D. 2010. Sheep and goat production and marketing systems in Ethiopia: Characteristics and strategies for improvement. Improving Productivity and Market Success (IPMS) of Ethiopian Farmers Project, International Livestock Research Institute (ILRI), Addis Ababa, Ethiopia . Working Paper No. 23

[17] Ayele G, A. Jabbar M., Teklewold H., Mulugeta E. and Kebed G. 2006. Seasonal and inter-market differences in prices of small ruminants in Ethiopia. Journal of Food Products Marketing (USA), 12(4): 59-77.

[18] Rota A. and Sperandini S. 2009. Livestock and pastoralists. Livestock Thematic Papers Tools for project design. International Fund for Agricultural Development, Rome, Italy.
[19] Sebsibe A. 2011. Export requirements for meat and live small ruminants. How can development agents assist producers to improve small ruminant export? Technical Bulletin No.47

[20] Williams T.O., Spycher B. and Okike I. 2006. Improving livestock marketing and intra-regional trade in West Africa: Determining appropriate economic incentives and policy framework. ILRI (International Livestock Research Institute), Nairobi, Kenya. 122 pp.

[21] Farmer, E. 2010. End Market Analysis of Ethiopian Livestock and Meat. A Desk Study Micro report 164

[22] Delil F., Asfaw Y. and Gebreegziabher B. 2012. Prevalence of antibodies to peste des petits ruminants virus before and during outbreaks of the disease in Awash Fentale district, Afar, Ethiopia. Trop Anim Health Prod, 44:1329-1330

[23] Regassa F. Netsere M., Tsertse T. 2010. Sero-Prevalence of Contagious Caprine Pleuropneumonia in Goat at Selected Woredas of Afar Region. Ethiop. Vet. J., 14(1), 83-89

[24] Zewdie S., 2009. Peste des Petits Ruminants (PPR). Ethiopia Sheep and Goat Productivity Improvement Program (ESGPIP). Technical Bulletin No.20

[25] Dawit, T. 2006. Seroprevalence study of peste des petits ruminants in Gewane district, Afar Regional State, Ethiopia. Unpublished DVM thesis, Addis Ababa University

[26] Aklilu, Y. 2008. Livestock Marketing in Kenya and Ethiopia: A Review of Policies and Practice. Feinstein International Center, Addis Ababa

[27] Gekara O, Leite-Browning ML, (2012). Biosecurity Practices for Small Beef Cattle Producers. A Series for Small-Scale Producers and Hobby Owners.

[28] Anderson David E. 2010. Survey of Biosecurity Practices Utilized by Veterinarians Working with Farm Animal Species. The Online Journal of Rural Research and Policy 5.7: 1-13.

[29] Van Schaik G, Dijkhuizen AA, Benedictus G, Barkema HW, Koole JL 1998. Exploratory study on the economic value of a closed farming system on Dutch dairy farms. Veterinary Record 142: 240-242.

[30] Van Schaik G., Nielen M., Dijkhuizen, A.A. 2001. An economic model for on-farm decision support of management to prevent infectious disease introduction into dairy farms. Preventive Veterinary Medicine 51: 289-305.

[31] Lawrence M., Riccardo C., Ibrahim O.O., Samuel O.O., Jabbar M., Negassa A. and Amos O. 2008. - A rapid appraisal of institutions supporting Somali livestock export. Improvement and Diversification of Somali Livestock Trade and Marketing Project. Discussion Paper No. 14. Improving market opportunities. International Livestock Research Institute, Nairobi.

[32] Negassa A., Costagli R., Matete G., Jabbar M., Oyieke S.O., Abdulle M.H. and Omore A. 2008. Towards improving livestock export marketing support services in the Somali context: survey findings and implications. Improvement And Diversification Of Somali Livestock Trade And Marketing Project. Discussion Paper No. 13. Improving market opportunities. International Livestock Research Institute, Nairobi. 